Grand Valley State University

ScholarWorks@GVSU

Summer 2013

\title{
Anti-Haitian Rhetoric and the Monumentalizing of Violence in Joaquín Balaguer's Guía Emocional de la Ciudad Romántica
}

Médar Serrata

Grand Valley State University, serratam@gvsu.edu

Follow this and additional works at: https://scholarworks.gvsu.edu/mll_articles

\section{ScholarWorks Citation}

Serrata, Médar, "Anti-Haitian Rhetoric and the Monumentalizing of Violence in Joaquín Balaguer's Guía Emocional de la Ciudad Romántica" (2013). Peer Reviewed Articles. 1.

https://scholarworks.gvsu.edu/mll_articles/1

This Article is brought to you for free and open access by the Modern Languages \& Literatures Department at ScholarWorks@GVSU. It has been accepted for inclusion in Peer Reviewed Articles by an authorized administrator of ScholarWorks@GVSU. For more information, please contact scholarworks@gvsu.edu. 


\title{
ANTI-HAITIAN RHETORIC AND THE MONUMENTALIZING OF VIOLENCE IN JOAQUÍN BALAGUER'S GUÍA EMOCIONAL DE LA CIUDAD ROMÁNTICA
}

Médar Serrata

Grand Valley State University

The life of things is in reality many lives.

—Philip Fisher, “The Future’s Past” (587)

"L'histoire est trop riche, trop multiple et trop profonde pour se réduire au signe de pierre qui s'en est échappé."

-Marc Augé, Le temps en ruines (38-39)

\begin{abstract}
This essay compares four editions of the book Guía emocional de la ciudad romántica, by the Dominican author and politician Joaquín Balaguer. The book, a celebration of Santo Domingo's monumental architecture, evokes the topos of the romantic poet who strolls down the streets of an ancient city admiring the remnants of the past. A closer examination, however, reveals a text deeply invested in the monumentalizing of violence ${ }^{1}$ - a text that portrays the dictator Rafael Leónidas Trujillo as the
\end{abstract}

\footnotetext{
Many thanks to Lily Litvak for her insightful suggestions and support in preparing this essay. I am also grateful for the editorial assistance of Michelle Sánchez, Paloma de la Cruz, Rebeca Castellanos, Christa Pruden, and the anonymous reader of Hispanic Review.

1. I have borrowed the phrase "monumentalizing of violence" from W. J. T. Mitchell (378).
} 
savior of the nation. Moreover, the metaphorical stroll that the reader is invited to take reenacts the movement of history in order to justify the 1937 massacre of thousands of Haitians living in Dominican territory.

The first epigraph above refers to the series of changes that an artifact undergoes before finding itself in a Western museum. The second describes the limitations of a historicizing project that purports to read the ruins of an ancient city as unambiguous signs of the past. I have juxtaposed them here to suggest that architectural monuments display the signifying structure of artifacts in a museum. Indeed, the life of monuments is also many lives, to the extent that, just like collectible artifacts, monuments have been disconnected from the flow of daily experiences and turned into something other than what they were meant to be. They are no longer places for work, prayer or housing, but points of access to the past, pathways to the achievements of a great civilization we may never fully understand.

The architectural monuments of colonial Santo Domingo are a case in point. Founded in 1496 by Christopher Columbus's brother Bartholomew, the city was destroyed by a powerful hurricane in 1502 and then rebuilt on the opposite side of the Ozama River by Governor Nicolás de Ovando, following the grid model characteristic of ancient Roman towns. ${ }^{2}$ Santo Domingo became the point of departure for Spain's imperial enterprise and the site of many firsts, including America's first monasteries and convents, as well as the first cathedral, the first city hall, the first military fortress, and the first university. After the conquest of Mexico and Peru during the early sixteenth century, however, Spain lost interest in the colony. As Santo Domingo slowly degenerated into social and economic decay, many of the edifices erected during the colonial period deteriorated due to natural disasters, pirate attacks, wars, or neglect. Yet by the second half of the nineteenth century, these structures found new meaning when the Dominican ruling

\footnotetext{
2. As Erwin Walter Palm explains, the grid plan was the reflection of a centralized power resulting, in most cases, from an imperialistic impulse that attempted to impose a rational order on the conquered peoples (64). Appointed in September 1501 to impose law and order in Santo Domingo, Ovando was an experienced comendador in the Spanish borderlands who took part in the wars against the Moors. He continued the Indian repartimientos initiated by Columbus and launched military campaigns in the unconquered regions of Higüey, in the east, and Jaragua (or Xaraguá), in the west, where he "coldly executed the Indian chieftains and proceeded to entrust their communities to his own men" (Moya Pons 32-33).
} 
class discovered the advantages of using them for their project of civilizing an unruly population.

The first official measure aimed at turning Santo Domingo's colonial structures into monuments took place in 1870 , just five years after the country regained its independence from Spain. Proclaiming that all the "civilized" nations of the world showed a profound respect for their monuments, which they regarded as the purest source of history, the presidential decree sought to affirm a Dominican national past by placing a distinctively Western frame around the city's historical sites (Colección de leyes 205). ${ }^{3}$ The measure highlighted the elite's ambivalent attitude toward Spain, as it established a relationship of continuity between the Dominican Republic and the same power from which it had broken away. Such ambivalence can be attested to in the works of poets and novelists writing at the turn of the century, in which the ruins of Santo Domingo stand as a master signifier of Dominican identity. ${ }^{4}$ But the strategy of using the symbolic nature of monuments as an instrument of civilization may never be more readily accessible than in Guía emocional de la ciudad romántica, by Joaquín Balaguer (1906-2002).

A seemingly innocent celebration of Santo Domingo's monumental architecture, the embellished text and photographs of Guía emocional evoke the topos of the romantic poet who strolls down the streets of an ancient city admiring the remnants of a glorious past. A closer examination, however, reveals a text in search of a legitimizing origin for totalitarian power-one in which colonial Santo Domingo stands as the last bastion of Western civilization. This essay explores the transformations that the book underwent as Balaguer sought to adapt it to the changing political reality of the Dominican Republic without renouncing the force of its ideological thrust. As an intertextual reading of the different versions will show, in the guise of a harmless coffee-table book, Guía emocional de la ciudad romántica rearticulates the arguments deployed by the government to justify the massacre of thousands of Haitians living in Dominican territory in October of 1937.

\footnotetext{
3. The notion that a building could represent an absent reality is an invention of the nineteenth century, when for the first time structures were preserved not because of their practical value but because of their historical meaning. It was at this time that the very concept of monument, like the concepts of historical and artistic restoration, emerged (Navascués 6o).

4. Some significant examples include Salomé Ureña's celebrated poem "Ruinas" (1876), Manuel de Jesús Galván's Enriquillo (1879), and César Nicolás Penson's Cosas añejas (1891). The relationship between city and nation reached a heightened level of complexity in the works of modernista writer Tulio Manuel Cestero, who problematized the topic in his novels Ciudad romántica (1911) and La sangre (1915).
} 
The author of more than fifty volumes-including several books of poems and essays of historical interpretation, as well as a novel, a study on Spanish versification, and a history of Dominican literature-Balaguer is also considered one of the country's most influential politicians of the twentieth century. Balaguer, who ruled the Dominican Republic for twenty-two nonconsecutive years between 1966 and 1996, began his career in 1930 as an obscure public servant under the brutal dictatorship of Rafael Leónidas Trujillo. His rise to the top of the power structure has been linked to the publication of La realidad dominicana: semblanza de un país y de un régimen (1947). In this book, which became the centerpiece of official discourse and consolidated his reputation as an ideologue of the regime (Cassá 395), Balaguer sought to legitimize Trujillo's claim to power by portraying the dictator as a messianic figure predestined to rescue the Dominican Republic from a long history of political disarray and economic backwardness. This was a myth adopted by many other Trujillista authors, ${ }^{5}$ but what sets Balaguer's work apart is the pseudoscientific rhetoric he adopted to portray Dominicans as racially and culturally superior to their Haitian neighbors. Trujillo, Balaguer claimed, understood that to save the essence of the nation from the Haitian threat it was necessary to strengthen the racial difference between the two peoples by implementing a demographic policy aimed at preventing the number of blacks in the Dominican Republic from ever being greater than the number of whites and mestizos (La realidad dominicana 116). This policy also entailed an effort to instill in Dominicans an appreciation for their Spanish heritage. The campaign continued well beyond the end of Trujillo's government, with the restoration of the city's monuments and the construction of the Columbus memorial lighthouse, a massive structure erected as part of the commemoration of the Christopher Columbus Quincentenary in 1992. ${ }^{6}$

5. The group of intellectuals who worked in the service of Trujillo's dictatorship was comprised of some of the most respected writers and scholars of the time, including Jacinto Peynado, Arturo Logroño, Ramón Emilio Jiménez, Virgilio Díaz Ordoñez, Emilio Rodríguez Demorizi, Manuel de Jesús Troncoso de la Concha, Max Henríquez Ureña, Ramón Marrero Aristy, Tomás Hernández Franco, and Manuel A. Peña Batlle, among others. Of these, only Peña Batlle is considered to have surpassed the level of ideological coherence achieved by Balaguer. For more on the role of Trujillo's intellectuals, see Andrés L. Mateo, Mito y cultura en la Era de Trujillo. For an analysis of the Trujillista discourse, see my article, "Poética de la dictadura."

6. More than 20,000 families were displaced by the program of urban renewal implemented by Balaguer during the 1980 s in preparation for the Quincentennial (Morel and Mejía 96). The Columbus lighthouse, which was the centerpiece of the celebrations, had been a dream of the Spanish American elite since the nineteenth century. Its construction was set to begin in the early 1940s, under the auspices of the Pan-American Union and Trujillo's government, but it was soon 
Guía emocional de la ciudad romántica played a role in this project to define Dominican identity in terms of a Eurocentric view of the national history, and as such the book mirrors the line of continuity between Trujillo's dictatorship and Balaguer's own terms as president.

\section{The History of the Book}

Guía emocional is Balaguer's most reprinted book, having seen four editions in a span of five decades $(1944,1969,1973$, and 1992). Coincidentally playing into the author's penchant for historical symmetry, the first edition appeared in a year in which Dominicans commemorated the centennial of their independence from Haiti, ${ }^{7}$ while the fourth dovetailed with the anniversary of Columbus landing in the Americas. The changes that the book underwent during this period pose a challenge similar to the one faced by specialists in the Middle Ages, who frequently found themselves in the position of having to establish the text before proceeding to analyze it. Indeed, which edition should we refer to when discussing Guía emocional? It would be tempting to take the glossy 1992 version as the definitive text, considering that it was the last one published in the author's lifetime. But wouldn't that entail erasing the history of the book-a history that could perhaps tell us as much about the complexities of its production as about the relationship between language, image, and power? On the other hand, by privileging the first edition we could miss a unique opportunity to see how the disciplinary discourse of monumental history can find renewed life under the conjunction of literary and visual representations. A more productive approach would be to retrace the path of the four versions, beginning with the most recent before finding our way back to the original, in order to recover the meanings it lost and discover those that it gained through its many transformations.

The glossy 1992 edition of Guía emocional combines prose, poetry, and photography in a craftily composed artifact located halfway between the genre of the historical essay and the art-book form that André Malraux

\footnotetext{
interrupted due to the Second World War. Balaguer resurrected it during his fourth presidency at an estimated cost of 100 million dollars (Greene 176). For a history of the project, see Edgardo Rodríguez Juliá.

7. Haiti occupied the present-day Dominican Republic on February 9, 1822. The twenty-twoyear occupation that followed reinforced the nationalist sentiments of the Dominican elite and exacerbated its prejudice against blacks (Despradel 89).
} 
described as a "museum without walls." The book is divided into five main sections: "La fisionomía moral de la ciudad," "La ciudad monumental," "Nicolás de Ovando, apóstol de la civilización," "Datos históricos acerca de los principales monumentos coloniales," and the twenty-four poems in sonnet form grouped under the title "Ofrenda lírica." It also includes an appendix with historical and topographical information, as well as a section entitled "La ciudad moderna" dedicated to the structures built outside the walls of colonial Santo Domingo, many of them during Balaguer's administrations. This section and the nearly one hundred full-color photographs by Ángel W. Martínez that accompany the text are a departure from the book of 1974, illustrated by Santo Domingo's visual chronicler Max Pou. Pou's suggestive photos, with their empty spaces and their interplay of light and shadow, also provide the visual narrative for the 1969 edition—a leaner book of only one hundred and forty pages and fifty-one illustrations. The "Ofrenda lírica," along with the images found in the last two sections of 1974 , are missing.

The most striking modifications, however, can be seen between the 1969 and the 1944 texts. As we move one step further toward the original version, we are surprised to find that the visual component—so important in the later editions that it could even give the impression of being the main purpose of the book-was not part of the original design. More modest than its later incarnations, the original work features only two images. The first one is a photograph of General Trujillo with the following caption on page 4: "Su Excelencia el Generalísimo Dr. Rafael L. Trujillo, Benefactor de la Patria, y la más alta cifra humana en el panorama político y moral de la República." The second is a portrait of a long-bearded Ovando, appearing much thinner and more somber than in the drawing of the later editions. The 1944 text also has two chapters that do not appear in the illustrated versions of the book: "Ciudad Trujillo, la ciudad moderna," and "Historia del cambio de nombre de la ciudad de Santo Domingo al de Ciudad Trujillo."

The presence of the Generalísimo in the Guia emocional of 1944 requires that we bring into our discussion the political context in which the book was produced, in order to consider to what extent the original text was Balaguer's contribution to what Dominican scholar Andrés L. Mateo has termed "the foundational myth" of the Trujillo Era (116). At the center of this myth was a powerful storm that ravaged Santo Domingo in 1930, killing about two thousand people. Hurricane San Zenón caused damage to the agriculture of the south and destroyed over fifty percent of the city's buildings, erasing the 
old hierarchies inscribed in the residential segregation of citizens by social class (Derby 68). Although the government concentrated its efforts on the capital city, Trujillo's propaganda apparatus turned la reconstrucción into a sign of the nation's rebirth. Two years later, in 1932, the Dominican Congress passed an emergency bill to honor Trujillo with the title "Benefactor de la Patria" (as he appears in the caption), soon to be followed by that of "Padre de la Patria Nueva." In 1935, as a token of appreciation for the reconstruction works, the Dominican Senate introduced a bill to change the name of the city to Ciudad Trujillo.

In the mythological system articulated by Trujillo's intellectuals, the construction worked in tandem with the 1937 massacre of up to twenty thousand Haitians living in the Dominican Republic, persecuted and killed by machete-wielding members of the Dominican army. ${ }^{8}$ Balaguer played a prominent role in the aftermath of this genocide, first in his position as Acting Foreign Minister, and later as a member of the intellectual elite that took up the task of reconfiguring the killings by portraying Haitians as a threat to the survival of the Dominican nation. His work at minimizing the impact in the international arena started shortly after the onset of the massacre, when the first reports had yet to reach news outlets. In an official letter dated 10 October 1937, addressed to Evremont Carrié, the Haitian diplomatic envoy to the Dominican Republic, Balaguer downplayed the magnitude of what he called minor incidents connected to recent thefts perpetrated by Haitians in the region ("Notas" 52). Eight years later, Balaguer, at the time a diplomatic envoy in Bogotá, referred again to the massacre in an open letter to prominent Colombian intellectuals who had criticized Trujillo's antiHaitian policies. Arguing that due to the uniqueness of its situation the Dominican Republic could not be judged by the same criteria used to judge other countries, Balaguer maintained the government's version of the story-although this time he gave the illegal acts attributed to the victims a new historical weight:

Los sucesos de 1937, los cuales los enemigos del gobierno dominicano han tratado de pintar en el exterior como una inicua masacre de inermes masas

8. While historians have offered diverse explanations for the massacre, most accounts agree that the events of 1937 sprang from "the old Dominican aspiration to 'whiten' their race" (Vega 23). The origins of these aspirations have been traced back to the colonial system implemented by the Spaniards in the Caribbean, which effectively translated social inequality into racial difference (Despradel 83). 
haitianas, fueron el estallido en el alma de nuestro campesino, de un sentimiento de defensa y de protesta contra cuatro siglos de depredaciones realizadas en las provincias del norte del país por grandes bandas de merodeadores haitianos. ("Carta" 505; my emphasis)

This official representation of the massacre is especially interesting because of the implicit information it provides. Balaguer no longer appears so eager to deny the magnitude of the killings; instead, he seeks to justify them by appealing to what seems at first an expression of nationalistic zeal. On the other hand, Balaguer's claim that the "depredations" that elicited such feelings had been taking place for several centuries effectively adds a whole layer of meaning to his previous strategy of incrimination. He cannot be referring to Haitians proper, since Haiti was only created in 1804 . Then what exactly does he mean?

In the 1945 letter, Balaguer pits Dominicans against their neighbors by arguing that Haitians were a permanent threat to the very existence of the Dominican Republic. He characterizes his fellow citizens as predominantly Spanish and Catholic, whereas Haitians were of "raza africana" and practitioners of what Balaguer considered "animismo de la peor clase" (504). The problem that the constant flow of immigrants with a "primitive" quality of life represented for the Dominican Republic was compounded by the rapid growth of the Haitian population. Trujillo had to put a stop to that wave of "Haitianization" that threatened to devastate his country. His efforts to protect the border guaranteed the survival of the Republic as a Christian nation: "Esa empresa equivale a fijar definitivamente la constitución histórica de la República y puede compararse, guardadas desde luego las distancias, con la que realizó Isabel la Católica para extirpar de España a la morisma y para mantener la pureza de la religión con el memorable edicto de 1492" (505). Balaguer thus compares the Dominican-Haitian conflict to the conquest of Granada, the last Moorish kingdom in the Iberian Peninsula, and to the expulsion of the Jews from Spain. This comparison is repeated almost verbatim in La realidad dominicana, where Balaguer claims, "la extirpación del merodeo de las comarcas fronterizas no es una de esas tareas que pueden cumplirse fácilmente sin efusión de sangre" (91). The analogy effectively brings the present crisis beyond the limits of a national conflict and imbues it with the meaning of a centuries-long racial and religious struggle. In Balaguer's model, the people killed in 1937 were not merely citizens of a foreign country, but representatives of the "African race," and consequently the 
sworn enemies of Christianity. Seen in this context, the reference to "cuatro siglos de depredaciones" makes perfect sense, since in his letter Balaguer portrays Haitians as the direct-and only-descendants of the African slaves brought to the island in the sixteenth century. The massacre is thus reconfigured through a two-tiered rhetorical move oriented to draw the Colombian intellectuals into an everlasting crusade against the "pagans." In the first tier, the conflict is projected back to the beginning of the colonial period but remains within the spatial limits of the island; in the second, it acquires a much broader scope as a sequel to the wars of Christians against Moors and Jews in the Iberian Peninsula.

\section{The City as Museum}

The parallel between the "Dominicanization" of the border and the homogenizing campaign implemented by Isabella of Castile provides a key for an interpretation of the relationship between text and image in the illustrated versions of Guía emocional de la ciudad romántica. Indeed, the incorporation of photographs of the city's colonial buildings can be read as an attempt to transform Santo Domingo into an "ideal museum" through which the reader is invited to reenact the nation's experience of self-discovery. ${ }^{9}$ Mechanically reproduced and redistributed within the contained space of the book form, monuments stand as visual representations of an absent reality. To access the meaning of these representations, the reader is expected not just to see the photographs but, as Tony Bennett says of the community of objects displayed in a museum, to see through them, in order to "establish a communion with the invisible to which they beckon" (35). A representation of another representation (the monument), each photograph thus appears two steps removed from the invisible reality it evokes: the Spanish essence of the Dominican cultural identity. Yet if "the existence of reproductions is what makes something an original" (Culler 160), ${ }^{10}$ the photographs that accompany Balaguer's

9. The concept of "ideal museum" is developed in Philip Fisher, who observes that the act of walking through a museum recapitulates the motion of history: "Viewing the pictures sequentially as we move from room to room, we follow the room numbers, the centuries, the schools. Insofar as the museum becomes pure path, abandons the dense spatial rooms of what were once homes, or, of course, the highly sophisticated space of a cathedral, it becomes a more perfect image of history" (591-92; emphasis in original).

10. Timothy Mitchell makes a similar argument in Colonising Egypt. According to him, "the structure of meaning in a system of representation arises ... from the distinction maintained between the realm of representation and the external reality to which it refers. Yet this real world, outside 
poetic prose help constitute the monuments as the authentic signifiers of that essence while inscribing them in a perpetual present. In this present, Marc Augé points out, the space that separates the representation from the past disappears (75).

The role of the photographs in the transformation of the colonial city into an ideal museum is reinforced by the distribution of the monuments in the topography of the text, and by the narrative coherence that their sequential order arouses. This is where the metaphor of the stroll becomes crucial, since the meaning of the visual component of the book as a whole relies on the beholder's ability to see each photograph as one stage in the nation's history. The metaphor of the stroll creates the illusion of temporality, uniting the discontinuous images of the monuments in a single storyline. The centerpiece of this narrative may be found in the sequence of photographs that illustrates the section "La ciudad monumental." The series begins with the petrified Ceiba tree to which, according to legend, Christopher Columbus tied his vessel, and continues with the Cathedral of Santa María la Menor (Figs. 1 and 2); then Columbus's Palace; the Dominican Convent; the Ruins of St. Francis (Fig. 3); the Church and Convent of Our Lady of Mercy; the Church of Regina Angelorum; the ruins of St. Nicholas; and finally the Count's Bastion. A look at a plan of the city (Fig. 4) shows that this itinerary does not make sense from a pedestrian's point of view. It would have been much easier, for instance, to go from the Ceiba tree to Columbus's Palace nearby, than to walk all the way down to the Cathedral, further south. And once at the Cathedral, why go back north to Columbus's Palace if the Dominican Convent is just a couple of blocks away?

As we move from image to text, it becomes apparent that Balaguer's virtual tour is not governed by the distribution of buildings throughout the urban space. His is not the carefree walk of the flaneur, roaming the streets of a modern city with no purpose in mind. The subject of his promenade has little in common with the strolling urbanite famously described by Walter Benjamin. Whereas the flâneur "seeks refuge in the crowd" and is at home in the illuminated arcades of Paris (Benjamin 40), Balaguer's narrator walks alone through the empty streets of colonial Santo Domingo. But more

the exhibition, seems actually to have consisted only of further representations of the real" (xiv). For a discussion of the structural difference between the tridimensional space of buildings and the space of painting, see Georg Simmel (371). 


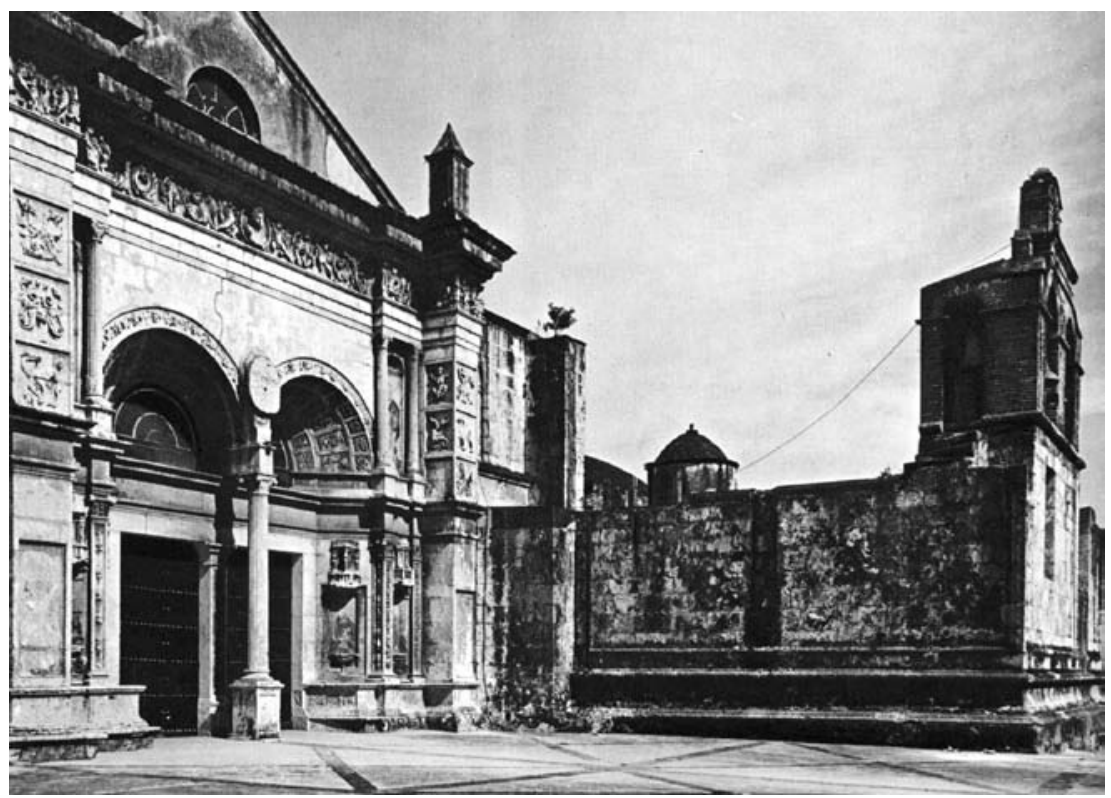

Figure 1. Facade of the Cathedral of Santa María la Menor. Guía emocional de la ciudad romántica (1969). Reprinted with permission.

importantly, the apparent meandering of Balaguer's walk conceals the preestablished pattern that replaces the casual gaze of the flâneur with a "highly directed and sequentialized practice of looking" (Bennett 186-87). In the illustrated versions of the book, the pattern revealed by the overall progression of the landmarks along this walk begins with an ascending movementfrom the arrival of the Spaniards to the city's apogee in the sixteenth century-followed by a fall during the period that led to the Haitian occupation, to conclude with the promise of a new ascent after the birth of the Republic. In the 1944 text, however, the romantic promenade does not end with the declaration of independence from Haiti but with the emergence of Trujillo's Patria Nueva, as the motion of history that the reader reenacts describes the transfer of symbolic power from colonial Santo Domingo to Ciudad Trujillo.

The promenade that the illustrated versions of the book provide as a visual experience reappears in the text in the form of an explicit invitation to the reader to embark on "una excursión emocional bajo la noche llena de silencios inmóviles, por la vieja ciudad que aún permanece encerrada en el anillo 


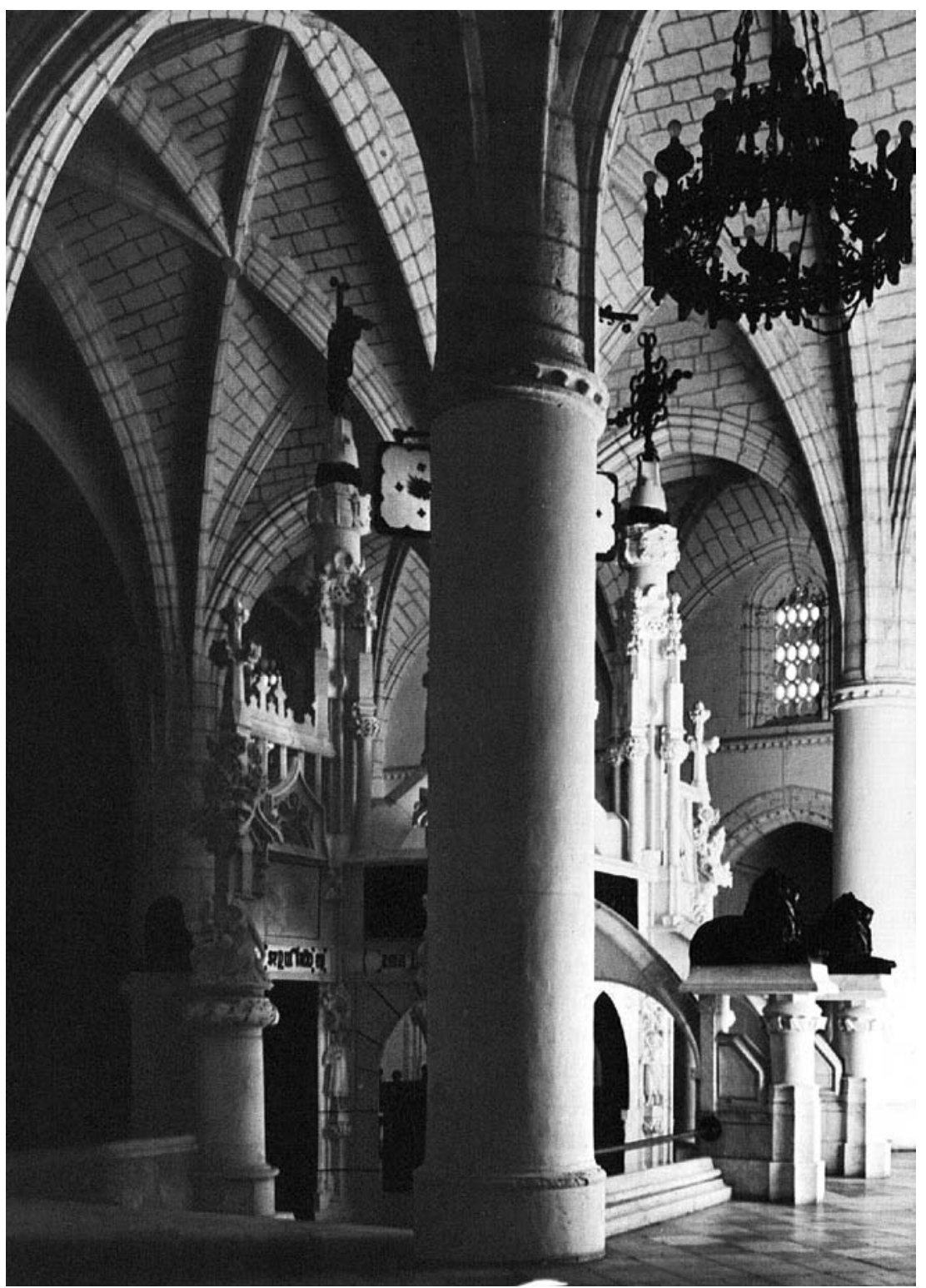

Figure 2. Interior of the Cathedral of Santa María la Menor. Guía emocional de la ciudad romántica (1969). Reprinted with permission. 


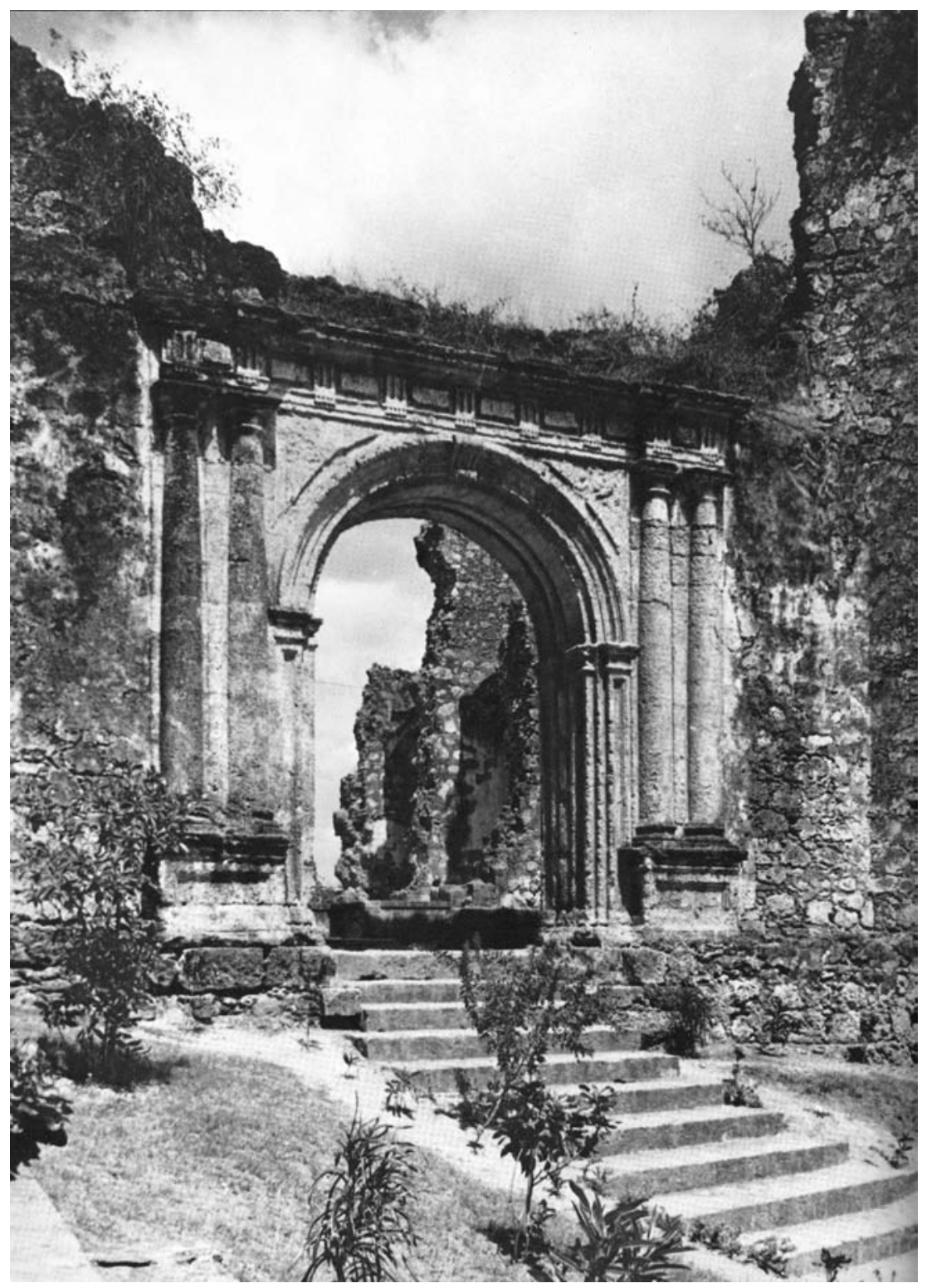

Figure 3. The Ruins of San Francisco. Guía emocional de la ciudad romántica (1969).

Reprinted with permission. 


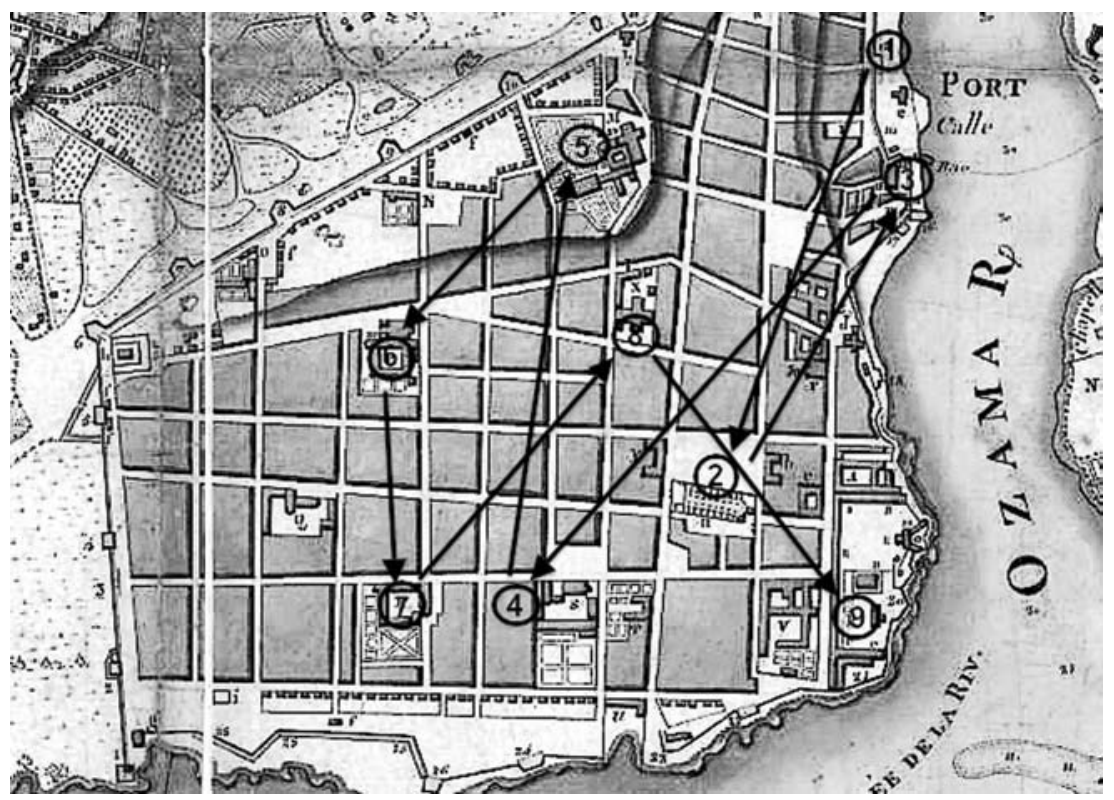

Figure 4. Itinerary followed by the narrator of Guía emocional de la ciudad romántica, drawn by me on an 1805 map located at the Library of Congress, Washington, D.C. (http:// hdl.loc.gov/loc.gmd/g4954s.ctooo102).

de sus murallas seculares" (35). The overall structure of this walk is encapsulated in the section dedicated to the Ceiba tree, which in the economy of the text plays a more prominent role than what its photograph suggests, becoming the most important symbol of the city's rise and fall. Located at the intersection between nature and culture, the point where the New World's landscape meets Western civilization, the tree's history mirrors the history of the city. After the Ceiba tree lost its leaves, it was immortalized as a stone monument. Similarly, when colonial Santo Domingo entered into a period of inevitable decline, after having led the Western hemisphere in artistic and cultural development, it covered itself "con el manto cuatro veces secular de sus ruinas y se empinó sobre sus pies de roca para tocar también, con las almenas de sus castillos, el cielo de la inmortalidad" (37). It appears, then, that both the Ceiba tree and the city died when their bodies dried out and were covered with stone. But in Balaguer's view, it is thanks to the hardness of the stone that their spirits-plural manifestations of the single spirit of the West-achieved the prize of immortality.

The relationship between immortality and the resistance of stone recurs 
while describing the Cathedral, whose architecture is deemed "la más severa interpretación que se haya hecho del estilo gótico en suelo americano" (41). Comparing it to "aquellos seres de excepción en cuyas venas se mezclan varias razas," Balaguer writes that the old temple combined the Gothic, the Romanesque, and the Renaissance, "rompiendo las disonancias de sus líneas para acomodarlas a un acorde unísono en la severidad de su conjunto armonioso." Further on, he states that the lower part of the façade exhibits the severity of the Romanesque, adding that this style was the most vigorous expression of Rome during the time when "el águila imperial abarcaba con sus alas la redondez del mundo" (43). In this manner, the spirit of Rome, through a metonymical chain of signifiers, materializes in one of Santo Domingo's most representative monuments-a process made possible thanks to the Roman virtue of severitas that secured the building's permanence in time. ${ }^{11}$ It is from the severity of the Romanesque that these structures draw their everlasting life. Hardness creates the conditions of possibility for the manifestation of the immortal and the magnificent.

The motif of severity is also at the core of the section "Nicolás de Ovando, apóstol de la civilización," in which Balaguer narrates the story of the destruction of the city by the powerful hurricane of 1502 . A new city was raised from the ruins by the iron-willed comendador, who rebuilt it in his image, "con monumentos adustos como sus costumbres y con calles rectilíneas como su carácter de acero" (99). The passage of time has not been able to erase Ovando's work. Everything he built remains, while generations of men have come and gone. This amazing resilience derives from the deep spiritual connection between the city and Ovando. In Balaguer's depiction, the Governor becomes one with the city, and this unity, protected by Ovando's ruthless character, guarantees its permanence in time. Here is a man who would stop at nothing to push forward the wheels of civilization, even if that meant shedding the blood of innocent people. Referring to Ovando's execution of Anacaona and the other Taíno chiefs in an incident known as the Jaragua Massacre, Balaguer states:

\footnotetext{
11. The idea of Spanish America as an extension of the Roman Empire, a recurrent topic among Latin American thinkers since the nineteenth century, was at the center of Dominican essayist Pedro Henríquez Ureña's search of a distinctively American expression. In the words of Henríquez Ureña, the Latin American nations came into existence as part of this "imperial community," whose influence shapes their national cultures without hampering their claim to originality (413-14).
} 
La irreducible dureza de su carácter trasciende a sus acciones: cuando la princesa de Jaragua entorpece sus planes de organización, estimulando, en concilio de caciques, el instinto de la insumisión en sus tribus vociferantes, la lleva sin el menor escrúpulo a la horca; y cuando considera necesaria al progreso de la colonia la iniquidad de los repartimientos, persevera en esa práctica diabólica y lleva adelante con el hierro, del uno al otro extremo de la isla, su obra civilizadora. (100)

Although he describes the repartimientos as diabolical, in this passage Balaguer positions himself squarely on the side of Ovando's authority, imposing a narrative order in which the events enter in a problem-solution relationship. Seen in this context, Ovando's acts of violence are justified as a matter of good governance meant to remove an obstacle to the advancement of civilization.

Balaguer's account harks back to the sixteenth-century debate on Spain's right to colonize the Indies and to subject the native population to virtual slavery through the institution of the encomienda. The arguments he employs to justify Ovando resemble those of the sixteenth-century Spanish scholar Juan Ginés de Sepúlveda, who claimed that the natives were culturally inferior to the Spaniards, and that their "unnatural" crimes deprived them of their rights of dominium (Pagden 119). This line of reasoning, based on Aristotle's theory of the natural slave, was rebuked by Bartolomé de Las Casas, a priest of the Dominican order known as the Defender and Apostle of the Indians. In his Apologética historia, Las Casas dismantled Sepúlveda's thesis, arguing that the natives were free in the natural order and the treatment to which the Spanish colonists subjected them defied the principles of Catholic theology. Determined to alleviate the burden of the native population, Las Casas went as far as recommending the importation of African slaves-a recommendation of which he soon repented, acknowledging the injustice of the institution of slavery (Larrazábal 25-27).

It should not come as a surprise that Balaguer presents Las Casas's work in a very unfavorable light. In contrast to Ovando, Las Casas stands as "el más funesto de los hombres que atravesaron el océano para dirigir los destinos de América y modelar el barro del mundo nuevo . . . el gran iluso divinizado por la historia" (101). ${ }^{12}$ According to Balaguer, Las Casas and

12. In the later versions of the book, Balaguer changed the word funesto to an adjective of a different paradigm, calling Las Casas "el más noble de los hombres que atravesaron el océano" (1969: 104), which makes the second attribute (gran iluso) totally unexpected. 
Ovando shared religious beliefs and moral values. But when judged based on their achievements, Ovando was a man of genius who thought about the future, while Las Casas was a "retórico delirante" incapable of foreseeing the consequences of his actions (101). In sum, the work of Las Casas amounts to a tremendous error inspired by a compassionate ideal: "El establecimiento en las Antillas de una numerosa colonia de esclavos africanos que al cabo de poco tiempo debía de contaminar la raza con elementos espúreos y contribuir a la relajación de las costumbres públicas en la cuenca del Caribe" (102)..$^{13}$ It should be noted that Balaguer condemns Las Casas not because he considered the enslavement of Africans to be as unjust as that of the Amerindians, but because their presence "polluted" the racial mix of the future nations. Moreover, Las Casas's efforts to save a doomed people drew the Caribbean nations away from what Balaguer understood as their racial destiny - a mixture of white Europeans - and created the basis for the partition of Santo Domingo between two incompatible "races" and cultures: "El establecimiento en una isla con menos de ochenta mil kilómetros cuadrados, de dos tipos de civilización antagónicos y de dos razas entre las cuales no existe siquiera, como un punto de aproximación o de contacto, el vínculo espiritual del idioma" (102).

Balaguer's indictment of Las Casas invites a comparison with the open letter he wrote in 1945 to the Colombian intellectuals. Let us recall that in that letter Balaguer warned against the danger that Haiti represented for the survival of the Spanish and Christian values on the continent. He portrayed the Haitian Massacre as the natural reaction to four centuries of pillage, by equating Trujillo's anti-Haitian policies to the eradication of the Moors and Jews from Spain. In Guía emocional, Balaguer blames Las Casas for the introduction of the "spurious elements" of the African slaves that contaminated the "Hispanic race." According to Balaguer, Las Casas did not realize that the immortal work of civilization required acts of severity, such as destroying a weaker people. Had he not interfered with Ovando's work with the intention of protecting the natives, today the whole population of Santo Domingo would be white and centuries of racial conflicts would have been prevented. In another display of his inclination for historical symmetry, Balaguer here

13. Balaguer echoes the myth of Las Casas as the man responsible for the introduction of blacks into the Caribbean. The fact is that Spaniards had been using African slaves since long before 1517, the date in which he made the suggestion. 
establishes an implicit correlation between the Jaragua and the Haitian massacres. If in the letter to the Colombian intellectuals he connected the present to the past, relating the victims of the Haitian Massacre to the slaves brought to the island four centuries earlier, in Guia emocional the reference to the killings ordered by Ovando in the sixteenth century refers us back to the conflict of 1937. The Jaragua incident is a figura foreshadowing the mass killings of Haitians, which can now be understood as the fulfillment of the first. ${ }^{14}$ Separated in time by four centuries of struggle between a civilized Self and a barbarian Other, both events belong in the same stream of historical life. Both removed what Balaguer perceived as threats to the future of Western civilization.

\section{Saving the City from the "Ax of the Barbarians"}

The figural relationship between the two genocides is reinforced by an overt analogy between Ovando and Trujillo that appears in the 1944 text but was omitted in the later versions of the book. This analogy appears in the section "Trujillo, creador de la ciudad moderna," which relates the story of the devastating storm of 1930 and the reconstruction works that followed. Although the hurricane spared the stone edifices of the colonial district, in his poetic rendition of the catastrophe, Balaguer displaces the damage to the old city, which is symbolically destroyed before rising again to mark a new beginning. According to this tale of death and resurrection, all that had been built during the previous four centuries collapsed in a matter of hours, giving Trujillo occasion to recreate Ovando's work: “A Trujillo, como a Ovando en 1502, correspondió la gloria de levantar de nuevo aquella ciudad egregia, aquella ciudad maravillosa por las proyecciones de su espíritu en el tiempo y por el brillo cuatro veces secular de su historia" (111). ${ }^{15}$ In describing the ensuing reconstruction works as an accomplishment of superhuman proportions, Balaguer compares Trujillo to a sculptor, whose hand has the virtue of the chisel that chips at the stone so that a statue appears. "El conductor de multitudes," Balaguer writes, "cuando hermosea el medio en que se desarrollan

\footnotetext{
14. I use the term figura in the sense of phenomenal prophecy, "something real and historical which announces something else that is also real and historical" (Auerbach 29).

15. Balaguer reiterated the analogy in a 1952 conference entitled "El principio de la alternabilidad en la historia dominicana," in which he reasoned that the Dominican Republic was not ready for a democratic system (La palabra 173).
} 
sus actividades creadoras, cumple una misión semejante a la que lleva a cabo el artista cuando descorre el velo de la poesía o cuando tiende la túnica del arte sobre las fealdades de la vida" (112). ${ }^{16}$ Given the symbolic status of the city in Guía emocional, the effects of Trujillo's creative impulse expand to the Dominican body politic as a whole. In rebuilding the city, the leader's hand did not merely restore what was already there but actually created something entirely different: a new nation. This foundational moment is consecrated in the resolution to change the name of the city to that of Ciudad Trujillo, a decision that Balaguer defends against its critics abroad. ${ }^{17}$

The real source of the dictator's "creative" power is established in the portrayal of Trujillo as a man "de perfil cortante como el filo de las rocas," a description that brings to mind his characterization of Ovando (115). The author goes on to exalt Trujillo's disregard for democratic values, implying that democracy ran against the best interest of the nation. The Dominican leader, Balaguer writes, came out of the barracks to erect the empire of law, not to court the masses by bowing to their whims. Like Ovando before him, Trujillo appears to us as a man of strong determination, ready to do whatever he deems necessary to further the civilizing project. The analogy that links both men reveals itself in the universal scope of their actions. By imposing his iron will on the colony, Ovando created the platform for the spread of Western culture in the Americas. Centuries later, Trujillo would bring the Americas together in order to save their culture from an imminent danger, just like Demosthenes, "el primero que en el mundo antiguo soñó con dar a las repúblicas helénicas la cohesión necesaria para que pudiesen salvar su cultura y sobrevivir el hacha de los bárbaros" (118). Trujillo’s project could

16. One can hear in this passage echoes of Joseph Goebbels's notion of politics as art. In his novel Michael, Adolf Hitler's Minister of Propaganda suggests that the only difference between artists and politicians resides in their particular means of expression: "The statesman is also an artist. For him, the nation is exactly what the stone is for the sculptor. Führer and masses, that is as little of a problem as, say, painter and color" (15).

17. To be sure, Balaguer is not alone in mythologizing the reconstruction works. The epic motif that sprang out of the dictator's response to the hurricane was used again and again by many other Trujillista authors who depicted la reconstrucción as a superhuman achievement. To give just two examples, in a poem entitled "En el mapa, la Patria redimida," Héctor Incháustegui Cabral depicts San Zenón as, "la señal con que el cielo va anunciando / un doloroso parto de gigante” (108). For his part, poet and literary critic Pedro René Contín Aybar recasts Trujillo's response to the hurricane as a struggle between a hero and the forces of nature: "La lucha es desigual: un Hombre contra la Naturaleza, como en las antiguas fábulas de las antiguas mitologías. Y, semejantemente, vence el héroe" (99). 
be conceived as a call to the "civilized" republics of the continent to put aside their political disagreements and unite against a common enemy who threatened to destroy their culture. Balaguer does not seem to find it necessary to reveal the identity of this danger, an indication that he assumed his own anxieties to be shared by other intellectuals of the region. However, the movement of history that his Guía emocional replicates leaves little doubt that the enemy he writes about is none other than Haiti, understood not only as a historical reality but also as a synthetic representation of blackness. The romantic stroll through colonial Santo Domingo is thus meant to make the reader a participant in a reenactment of history that justifies the use of violence against this perceived adversary.

When comparing the illustrated versions of Guía emocional to the book of 1944 one must grapple with the fact that the omission of the chapters devoted to Trujillo also leaves out an important element of the work's figural interpretation of the national history-one in which the city built by Ovando stands as the legitimizing source of totalitarian power. Just like the colonial city Balaguer describes, the book itself had to be restored if this interpretation was to be saved from becoming a ruin. As we have seen, however, the removal of the dictator's name does not preclude the book's investment in the monumentalizing of violence. If anything, without La Patria Nueva as its final destination, the phenomenal prophecy announced by Ovando's actions remains always a looming possibility. We could also argue that violence is reinscribed in a more persuasive way with the mechanical reproduction of Santo Domingo's monuments. The fact that the ultimate representation of power in the history of the Dominican Republic could be replaced by those appealing photographs of colonial architecture is not a negligible one. It confirms the proposition that "much of the world's public art-memorials, monuments, triumphal arches, obelisks, columns, and statues-has a rather direct reference to violence in the form of war or conquest" (W. J. T. Mitchell 378). It also speaks of Balaguer's capacity to infuse new breath into an object that seemed doomed to become a relic of the past. In this sense, the life of Guia emocional de la ciudad romántica mirrors the life of the city Balaguer praised, from its inception in genocide to its eventual transformation into a museum withouth walls-a structured space where citizens could practice the way of looking that the construction of a "civilized" nation required. 


\section{Works Cited}

Augé, Marc. Le temps en ruines. Paris: Galileé, 2003.

Auerbach, Eric. "Figura." In Scenes from the Drama of European Literature. By Auerbach. New York: Meridian, 1959. 11-76.

Balaguer, Joaquín. "Carta de Joaquín Balaguer a los intelectuales colombianos." In Documentos del conflicto dominico-haitiano de 1937. Ed. José Israel Cuello. Santo Domingo: Ediciones de Taller, 1985. 503-08.

- Guía emocional de la ciudad romántica. Santiago: El Diario, 1944.

- Guía emocional de la ciudad romántica. Santo Domingo: Alpa, 1969.

- Guía emocional de la ciudad romántica. Santo Domingo: n.p., 1974.

- Guía emocional de la ciudad romántica. Santo Domingo: n.p., 1992.

—. "Notas de la Secretaría de Estado de Relaciones Exteriores a la Legación Haitiana." In Documentos del conflicto dominico-haitiano de 1937. Ed. José Israel Cuello. Santo Domingo: Ediciones de Taller, 1985. 51-59.

—. La palabra encadenada. Santo Domingo: n.p., 1975.

- La realidad dominicana: semblanza de un país y de un régimen. Buenos Aires: Ferrari Hermanos, 1947.

Benjamin, Walter. The Writer of Modern Life: Essays on Charles Baudelaire. Cambridge, MA: Harvard UP, 2006.

Bennett, Tony. The Birth of the Museum: History, Theory, Politics. London: Routledge, 1995.

Cassá, Roberto. Los doce años: contrarrevolución y desarrollismo. 2 vols. Santo Domingo: Alfa \& Omega, 1986.

Colección de leyes, decretos y resoluciones emanadas de los poderes legislativo y ejecutivo de la República Dominicana. Santo Domingo: García Hermanos, 1883. 205-06.

Contín Aybar, Pedro René. "Literatura en la Era de Trujillo." Renovación: Órgano del Instituto Trujilloniano 1.4 (1953): 92-107.

Culler, Jonathan. Framing the Sign: Criticism and Its Institutions. Norman: U of Oklahoma P, 1988.

Derby, Lauren. The Dictator's Seduction: Politics and the Popular Imagination in the Era of Trujillo. Durham, NC: Duke UP, 2009.

Despradel, Lil. "Las etapas del antihaitianismo en la República Dominicana: el papel de los historiadores." In Política y sociología en Haití y la República Dominicana. Ed. Gérard Pierre-Charles. México, DF: U Nacional de México, 1974. 83-106.

Fisher, Philip. “The Future's Past." New Literary History 6.3 (1975): 587-606.

Goebbels, Joseph. Michael: A Novel. Trans. Joachim Neugroschel. New York: Amok, 1987. Greene, Solomon J. "Staged Cities: Mega-Events, Slum Clearance, and Global Capital." Yale Human Rights and Development Law Journal 6 (2003): 161-87. General OneFile. Web. 19 Dec. 2011.

Henríquez Ureña, Pedro. "El descontento y la promesa." In Obras completas: escritos políticos, sociológicos y filosóficos. Santo Domingo: Nacional, 2004. 403-17.

Incháustegui Cabral, Héctor. "En el mapa la patria redimida." In Álbum simbólico: 
homenaje de los poetas dominicanos al Generalísimo Dr. Rafael L. Trujillo Molina, Padre de la Patria Nueva. Ed. Manuel E. Suncar Chevalier. Ciudad Trujillo: Ateneo Dominicano, 1957. 99-114.

Larrazábal Blanco, Carlos. Los negros y la esclavitud en Santo Domingo. Santo Domingo: Librería La Trinitaria, 1998.

Malraux, André. The Psychology of Art: Museum without Walls. Trans. Stuart Gilbert and Francis Price. New York: Doubleday, 1967.

Mateo, Andrés L. Mito y cultura en la Era de Trujillo. Santo Domingo: Manatí, 2004.

Mitchell, Timothy. Colonising Egypt. Berkeley: U of California P, 1991.

Mitchell, W. J. T. Picture Theory. Chicago: U of Chicago P, 1994.

Morel, Edmundo, and Manuel Mejía. "The Dominican Republic: Urban Renewal and Evictions in Santo Domingo." In Evictions and the Right to Housing: Experience from Canada, Chile, the Dominican Republic, South Africa and South Korea. Ed. Antonio Azuela, Emilio Duhao, and Enrique Ortiz. Ottawa: International Development Research Center, 1998. 83-144.

Moya Pons, Frank. The Dominican Republic: A National History. Princeton, NJ: Markus Weiner, 1998. 7.

Navascués, Pedro, and María Jesús Quesada Martín. El Siglo XIX: bajo el signo del Romanticismo. Madrid: Sílex, 1992.

Pagden, Anthony. The Fall of Natural Man: The American Indian and the Origins of Comparative Ethnology. Cambridge, UK: Cambridge UP, 1982.

Palm, Erwin Walter. Los monumentos arquitectónicos de La Española. 2nd ed. Santo Domingo: Sociedad Dominicana de Bibliófilos, 1984.

Rodríguez Juliá, Edgardo. Caribeños. San Juan: Instituto de Cultura Puertorriqueña, 2002.

Serrata, Médar. "Poética de la dictadura: el poder de las palabras en la Era de Trujillo." $50^{\circ}$ Aniversario de la Gesta del 30 de Mayo. Spec. issue of País Cultural 6.12 (2011): 64-77.

Simmel, Georg. "Two Essays: The Handle, and the Ruin." Hudson Review 11.3 (1958): $371-85$.

Vega, Bernardo. Trujillo y Haití. 2 vols. Santo Domingo: Fundación Cultural Dominicana, 1995. 